\title{
大阪大学嗅覚外来の現況
}

一嗅覚検査法と今後の展望一

瀬田 敬子1) - 竹本 市紅 ${ }^{1)} \cdot$ 肥塚 泉 ${ }^{1)}$
前谷 近秀2) - 岡田能理子 ${ }^{3)}$. 外池 光雄 ${ }^{4)}$

\section{Examination of the Sense of Smell}

\author{
Noriko Seta, Ichiko Takemoto and Izumi Koizuka \\ (Osaka University)
}

Chikahide Maetani
(Itami City Hospital)

Noriko Okada

(Tondabayashi Hospital)

Mitsuo Tonoike

(Bioelectronic Interface Section Osaka, LERC Electrotechnical Laboratory)

Smells and odors provide sense information that can serve to protect an animal from natural enemies. They also provide important information used in maintaining a genus. It has been said that the sense of smell will be lost with evolution, as evidenced by the fact that the sense of smell is not a dominant source of sense information for human beings. However, when suffering from smell disorders, humans newly discover the importance of this sense. In this paper, the physiology of the sense of smell is outlined and clinical examination of patients with smell disorders and dysfunctions are described. Moreover, the "olfactory evoked potential", a novel analytic method, is also presented.

Key words: sense of smell, physiology, clinical examination, olfactory evoked potential

はじめに

我々人類にとって，ふだん無意識に感じてい るニオイや香りは, 野生動物にとって天敵から
身を守ってゆくのに，またその個体を維持し種 属を保存していくためになくてはならない感覚 情報である。例えば，野生の動物の雌の性腺か

1) 大阪大学医学部耳鼻咽喉科学教室

2）市立伊丹病院耳鼻咽喉科

3) 富田林病院耳鼻咽喉科

4）電子総合研究所大阪ライフェレクトロニクス研究センター 
ら出るホルモンの一種であるフェロモンと言わ れる物質の二オイは, 雄を呼び寄せ, 種属保存 をはかるための重要な役割を果たしていること が知られている。サケは生まれ育った川を覚え ており成長して再び産卵に戻って来る話（母川 回帰）は有名である. 育った川の二オイがサヶ の脳にインプリントされるため忘れずに戻って くることができるからである，そのため産卵に 適した条件の川を自ら捜す必要がなく, 自然に 子孫に伝えることが出来るよらになっている。 哺乳類は生まれてすぐに触ったもの, 嗅いだも のを本能的に母親と思いこみ，それが毛布であ っても離れようとせず，無理に引き離すと食欲 がなくなり死に至ることさえある。これについ ては人間も例外でなく, 生後すぐの新生児は嗅 覚や触覚を媒体として母親と初めてのコミュニ ケーションを行ない, 生後 4 日の新生児では母 乳の二オイを感じとることが可能となる. 生後 1 ケ月で母親の母乳とミルクの二オイの違いが わかるよらになるため，この時期に母親に対す る認識を強くしていることがわかる．このよう に人間も生後まもなくは本能的に嗅覚に頼って いるようである。

嗅覚は進化により失われて行く感覚であると されているが，日本人にとっては太古から，特 に四季折々の変化を知る指標となっている.「梅 薫る」といった表現が現在でも使われ，この言 葉で季節感を味わらことが出来るのは, 湿気を 含んだ日本の気候ならではのことと思われる。 しかし, 現代の日本においては, 建築様式が洋 風化され, 人口密度が高くなるにつれ庭園が少 なくなり, 高層化も進及, 隣人との摩擦や, 周 囲からの干渉を避けるためには自ら防音, 防臭 を心がけるようになり，古代において生活に潤 いを与えていた香りというものに対する無関心 あるいは過剩防衛化が進んだ生活様式となって きている。

このよらな社会において, ニオイに関する問 題はすでに無視する事ができなくなってきてい る. ニオイの問題には, 大きく分けて嗅覚障害
による嗅覚脱失, 嗅覚減退や異臭症などの個人 的な嗅覚異常の問題, それ以外に悪臭による社 会的な公害問題がある. 現在行われている嗅覚 の検査法はいずれも，個人の判断に基ずく心理 的な主観評価法であるため個人差によるあいま いさなどの問題が上げられている，そこで我々 は 5 年前より嗅覚を客観的に計測することを目 的として, 脳波の計測による他覚的嗅覚検査の 試みを行っている.ここでは，まずニオイを感 じるメカニズムを簡単にまとめると共に, 嗅覚 障害患者に対して現在行われている検査法の特 徵をあげ, さらに我々が行っている嗅覚誘発電 位検査について, 経過を述べるとともに, 現在 までに得られた結果について考察を行ら.

\section{嗅覚のメカニズム}

人間は質的に約4000の異なるニオイを識別で きるといわれている.ニオイの強さに関しては， 強い二オイの識別は容易であるが, 微かな二オ イの識別をする能力は他の感覚より少っている. 食物から発する二オイ分子は空気中に飛散した 後, 吸気と共に鼻腔に入る.そして嗅上皮を被 っている粘液に溶解して上鼻甲介とそれに対応 する鼻中隔上部に存在する嗅上皮に到達する. 嗅上皮の面積は一側につき，およそ 100〜250 $\mathrm{mm}^{2}$ であるとされている. 組織学的には嗅細 胞, 支持細胞, 基底細胞からできており, 篩骨 篩板より鼻腔に進入してきた嗅神経が分布し， 嗅細胞内に終末している.ささらに粘膜下には多 数の Bowman 氏腺が分布して抢り, そこから 分泌される粘液が上皮を被っている，嗅上皮の 色調は他の呼吸上皮と比較して, 黄色あるいは 黄褐色を呈していると言われている.しかし実 際には視診上, 肉眼的あるいは内視鏡下にても, 他の上皮との識別は困難であることが多い.

人の嗅粘膜中には, 数十万〜数百万個の嗅細 胞がある、それぞれの嗅細胞は, 鼻孔から入っ てくる様々な二オイに反応して, その細胞体下 部にインパルスと呼ばれる活動電位を発生させ る.このインパルスの中に, 二オイの強弱, 時 間あるいは質の情報が符号化され，それぞれの 
嗅細胞の軸索を伝導して, 嗅覚の第一次中枢神 経系である嗅球に送られる。このように，嗅覚 神経は，二オイのセンサーとして，二オイ物質 がもつ化学的エネルギーを, 活動電位といら電 気的ェネルギーに変換する变換器の役割を果た している.

嗅細胞の中枢端は,きわめて細い無䯣神経と なって，篩板を貫いて，頭蓋腔に入り，嗅球に 終わる. 嗅球上り出る神経線維は, 旧皮質に属 する，いわゆる嗅皮質に投射している．嗅球の 全額断面では， 6 層に区別される，最外層は， 嗅神経線維層といい，嗅上皮から送られた嗅神 経が複雑な走行をしている. 第 2 層は糸球体層, 次の第 3 層の外網状層の最深部には僧帽細胞が 並び，主樹状突起をのばし嗅神経末端とシナプ スを形成している，嗅細胞からの情報は嗅神経 線維を介して嗅球の僧帽細胞へと送られる. 僧 帽細胞は興奮性のシナプス入力を受け軸索を嗅 皮質に投射している中継ニューロンである。し かし嗅細胞からの情報をそのまま嗅皮質へ中継 するのではなく，複雑な情報処理を行った結果 を送りだしている．また，近接した多数の僧帽 細胞は, 顆粒細胞との樹状突起間シナプスを介 して，自己抑制や相互抑制を行い，間接的に僧 帽細胞の活動をコントロールしている1).

\section{脳におけるニオイ情報処理のメカニズム}

1970年頃までの生理学的研究では, 視覚や聴 覚といった嗅覚以外の神経伝導路は, いずれも 感覚受容細胞から出発した線維が，必ず視床を 経由して新皮質の各知覚野に終わることが証明 されていた，しかし，嗅覚系だけは視床を経由 する伝導路が証明されていなかったために，視 床を経由せずに，皮質に存在する投射野に終わ ると考えられていた。そ後, 様々な研究が行 われ，1974年 Tanabe ら²)よって視床を経由 する経路が発見され，続いて，1977年には Yarita ら3)によって, 視床からでた線維が眼窩 前頭皮質の中央後部 (CPOF) に投射されること が証明された。また，Tanabe ら2)は視床を経 由する経路以外にも, 視床下部を経由して眼窩
前頭皮質の外側後部 (LPOF) に投射する経路が 存在することを発見した。

1979年 Takagi4) は，このようにして明らか

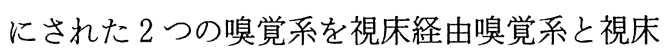
下部経由嗅覚系に分類した。また, 投射野 LPOF では，ニオイの識別にきわめて重要な意 味を持つことが証明され，その一方で, $\mathrm{CPOF}$ はニオイを総合的に判断する働きをしているの であろらと推定されている. このように，投射 野によって嗅覚の働きが異なることが明らかに なっている5)6).

\section{嗅覚障害の分類と病態}

ニオイを吸気によって取り込んでから, 認識 されるまでの伝達路に障害が起こることによっ て嗅覚障害が発現する。障害部位によっては予 後にかなりの差が認められ, 治療方針の決定に も障害部位の診断は欠かせないものとなってい る. そこで原因疾患とは別に臨床的に障害部位 によって嗅覚障害を分類している．まず嗅裂部 を通る気流が障害されるためにニオイ分子が嗅 粘膜に到達せずに起こってくる嗅覚障害を呼吸 性嗅覚障害と言い, その障害を引き起こす原因 疾患としては鼻茸, 慢性鼻炎のように単に鼻腔 が狭くなり嗅裂部に充分な通気ができないため に起こってくるもの, 慢性副鼻腔炎,アレルギー 性鼻炎など分泌過多を来すような鼻の疾患, 鼻 中隔弯曲症のように鼻腔内の形態異常などはす べてこの原因となる．また嗅粘膜そのものに障 害をおこしたために起こる嗅覚障害は嗅粘膜性 嗅覚障害と分類されている．その原因としては， ウイルス感染, 有毒ガス例えばシンナー, 有機 溶媒や殺虫剤などによる嗅粘膜の損傷, 頭頸部 腫瘍で放射線療法を行う場合照射野に嗅裂部が 含まれる場合などに起こる。このように嗅粘膜 に障害が扣こると嗅神経の末梢が障害されるこ とになり高位中枢への伝達系が障害され高度の 嗅覚障害となる場合が多い。呼吸性嗅覚障害を 扣こすものでさらに病変が嗅粘膜にまで波及し て嗅粘膜性嗅覚障害を合併したものを混合性嗅 覚障害としている. 最後に中枢性嗅覚障害は, 
嗅球よりも高位で障害を引き起こしたものを狭 義の中枢性嗅覚障害とし, 嗅球よりもさらに末 梢に障害が認められるものを末梢性嗅覚障害と

して分類している.

原因疾患としては頭蓋内腫瘍, 頭部外傷, 頭 蓋内手術後や先天性疾患等が挙げられる.

表 1 は, 平成元年度に大阪大学医学部耳鼻咽 喉科嗅覚外来を訪れた嗅覚障害患者の, 原因に より分類を行ったものである. 原因別症例数で は, 感冒後が $32 \%$ と最も多く, 次に特発性が 27 $\%$, 外傷性が $11 \%$, アレルギー性が $9 \%$, 慢性 副鼻腔炎に伴うものが $8 \%$ となっている.

\section{嗅覚検査法}

現在，嗅覚障害患者の診断検査法としては表 2 に示すように, T \& T オルファクトメー ター, 注射用のビタミン剤（アリナミン）を用 いた静脈性嗅覚検査, 針状鏡による嗅裂部の観 察, 嗅裂部のレントゲン写真撮影等が行われて いる。

$\mathrm{T} \& \mathrm{~T}$ オルファクトメーターは，1975年文 部省班研究によって開発された検査法で, 標準 的な嗅覚検査として日本全国で広く用いられて いる.この検査法は，日常生活でニオイを嗅い でいるのに最も近い状態での嗅覚検査を目的と して作られており， A：花のニオイ $\mathrm{B}$ : 焦げ たニオイ $\mathrm{C}$ : 腐敗臭 $\mathrm{D}$ : 果実の二オイ $\mathrm{E}$ : 萯臭の基準 5 臭を用いて検査を行ら。これ らの溶液を薄い汪らから高濃度の注らまで順番 に嗅いでもらい,初めて嗅感が得られた濃度(検

表 1 大阪大学耳鼻咽喉科嗅覚外来を訪れた患者 の原因別患者数

\begin{tabular}{|c|c|c|}
\hline 原因 & 患 者 数 & $\%$ \\
\hline 風 邪に続 発 & 56 & 31.8 \\
\hline 特 発 性 & 48 & 27.3 \\
\hline 外傷 性 & 19 & 10.8 \\
\hline アレルギー性鼻炎 & 16 & 9.1 \\
\hline 慢性副鼻腔炎 & 15 & 8.5 \\
\hline そ の 他 & 12 & 6.8 \\
\hline 合計 & 176 & \\
\hline
\end{tabular}

知域值）およびニオイの内容が認知できた濃度 （認知域值）の両者を測定し，その障害程度を 判定する.

静脈性嗅覚検査は, 静脈に注射されたアリナ ミンが肺に行き，特有のアリナミン臭が呼気中 に排出された後，このアリナミン臭が呼気と共 に後鼻腔を経由して嗅裂部に達し嗅刺激となる のを利用したもので，正常者では，注射後数十 秒で嗅感が出現し， 1 分から 1 分 30 秒の間, 嗅 感が持続するため，その潜伏および持続時間を 測定して異常かどらかを判定する.

針状鏡は直径 $1.7 \mathrm{~mm}$ の硬性鏡で，嗅裂部を 肉眼で直接観察することができる，嗅裂部の状 態を $\mathrm{N}$ 型 (正常型)， $\mathrm{O}$ 型 (腫脹型)， $\mathrm{S}$ 型 (分 泌型)，P型 (ポリープ形成型)， $\mathrm{A}$ 型 (萎縮型) に分類し，嗅裂部のレントゲン写真の結果と併 せて，嗅裂部の通過性，嗅球の状態などについ て知ることができる。これらの検査結果をもと に，呼吸性嗅覚障害，嗅上皮性嗅覚障害，混合 性嗅覚障害, 中枢性嗅覚障害などの部位診断が 可能となる.

ニオイの測定方法は，現在のところ今まで述 べてきたように，官能的検査法によるものが多 く用いられている。しかし，この方法は，個人

表 2 嗅覚障害診断のための検査

1) 耳鼻科的検査

鼻鏡検査

針状鏡検査

嗅裂部X線検査

2）自覚的検査法

静脈性嗅覚検査(アリナミンテスト)

T\&丁オルファクトメーター

3）他覚的検査法

嗅覚誘発電位

CNV (contingent negative variation) 
の判断に基づく心理的な主観的評価法であるた め個人差によるあいまいさ等の問題が残ってい る、そこで我々は，人の嗅覚を客観的に計測す る検査方法の開発を目的として, 生理学的に裏 つけされている脳波の計測による他覚的嗅覚 検査である嗅覚誘発電位, CNV (contingent negative variation) の計測を行った。

ニオイガネにより誘発脳波が得られることは すでに1966年 Finkenzeller?) や1967年 Allison \& Goff ${ }^{8)}$ によって報告されている. しかし得られ た波形については様々な議論が行われ，現在に 至るまでその起源についても諸説紛々である.

Smith ら9) はニオイガスの投与によって得られ る波形は，嗅覚誘発電位ではなく三叉神経刺激 により得られる波形であると推論している。一 方，大峡ら ${ }^{10)}$ は三叉神経刺激であることを否
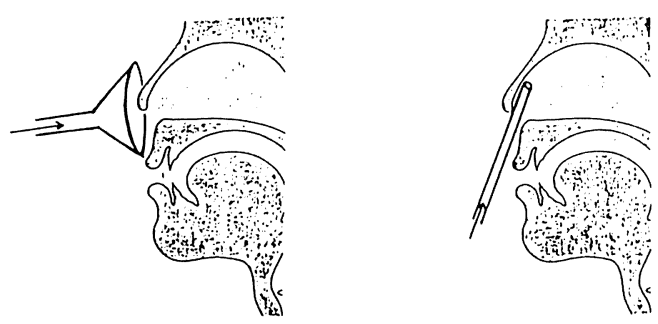

図 1 ニオイガス投与方法

左図: open method 右図 : blast method
定し嗅覚神経による誘発反応であると考察して いる. さらに, 最近では, Plattig ら11)は, = オイガスをパルス状に投与して嗅覚刺激だけ でなく三叉神経系も同時に刺激する pulse method を行った場合と，ニオイガス投与の合 間に Air を流して三叉神経による変化の影響を 少なくする flow method を行った場合とを比較 して, 前者のほらが発現する誘発波形の潜時が 短くなることを報告している．また，この变化 は三叉神経系の刺激の影響によるものと考察し ている. 同様に, Kobal ら ${ }^{12)}$ は嗅覚神経系と三 叉神経系が同時に刺激された場合, 嗅覚系が単 独で刺激された場合よりも有意に潜時が短くな ることを報告している。このように二オイガス によって得られた誘発反応が嗅覚神経系もしく は，三叉神経系いずれの刺激により引き起こさ れるものであるかが問題とされている.

そこで1987年に我々は13) 図1に示すように， まず漏斗を用いて二オイガスを鼻入口部に向か って投与する方法 (open method) と鼻腔内に直 接シリコンチューブを挿入して嗅裂部にニオイ ガスを直接投与する方法 (blast method) を用い て何れの方法がより良好な波形を誘発するかに ついて検討した。 その結果, やはり嗅裂部に直 接投与する blast method に上る刺激法が波形 を良好に誘発した。 blast method はさらに左右
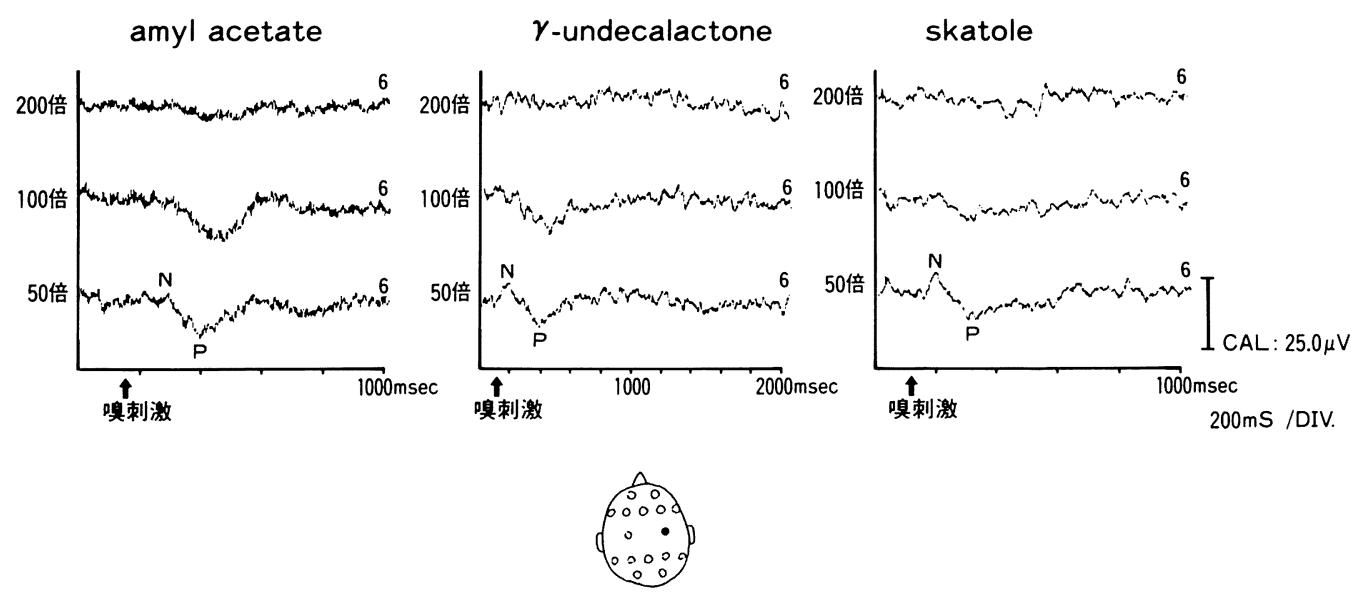

図 2 各ニオイガスにより得られた誘発電位の濃度による变化 (blast method) 
別刺激を行らことが出来るため刺激法として有 用であると思われる．1988年我々は14)，投与す るニオイガスの種類によって得られる誘発電位 にも違いが認められるかどらかについて blast method を用いて検討した。その結果，何れの ニオイガスにおいても誘発反応の各成分はほぼ 同様の潜時を示した。 またそのトポグラフも測 定したが各成分の分布の相違は認められなかっ た。一方ニオイガスの濃度に対しては濃度依存 性を示した（図 2 ）.

生体の情報処理に従って発生する大脳誘発電 位は，外的刺激依存性の外因性電位々，外的刺 激の存在には依存しない内因性電位の二種類に 区別されることが知られている．外因性成分は， 被験者に与えられた感覚刺激そのもののパラ メーターによって, 電位の潜時, 振幅, 頭皮上 の分布が変化するものであり, 内因性とは刺激 そのものでなく, 被験者が現に行っている課題 の種類や情報処理の程度によって出現パターン が変化するものである。この検査の結果では, 被験者により若干の個人差は認められるものの, 二オイの違いに関わらず，得られた誘発波は基 本的に同様の波形を示した。 また同一の被験者 に扣いてもそれぞれの被験者間に执いても良好
な再現性が得られていることより，得られた誘 発反応は外的刺激依存性の外因性電位である可 能性が高いと考えられた。

ニオイガス刺激による大脳誘発電位は嗅覚刺 激のみならず，三叉神経系に対する物理的刺激 による体性感覚誘発電位も混入している可能性 が示唆されている，そこで我々は，嗅裂部に無 臭空気を吹き付けて三文神経系だけを刺激した 場合と，ニオイガスを吹き付けて嗅覚系及び三 叉神経系をともに刺激した場合に得られる誘発 電位について検討を加えた。

我々は, blast method を用いて嗅覚誘発電位 の測定を行った．定量的なニオイ刺激をコント ロールし，一定のニオイをパルス状にして，被 験者の呼吸と同期させて，鼻腔内に投与するた めに，ニオイガスの発生拉よび投与はすでに外 池ら18) により報告されたニオイパルス刺激装 置を用いた。図 3 にブロックダイアグラムを示 す.

脳波の計測や加算には，日本電気三栄製のシ グナルプロセッサー7T18 を用いた. 加算回数 は嗅覚の疲労現象を考慮して20回とした．電磁 弁開放より実際にニオイガスが鼻腔に到達する までの遅れ時間はフィガロ技研製のエタノール

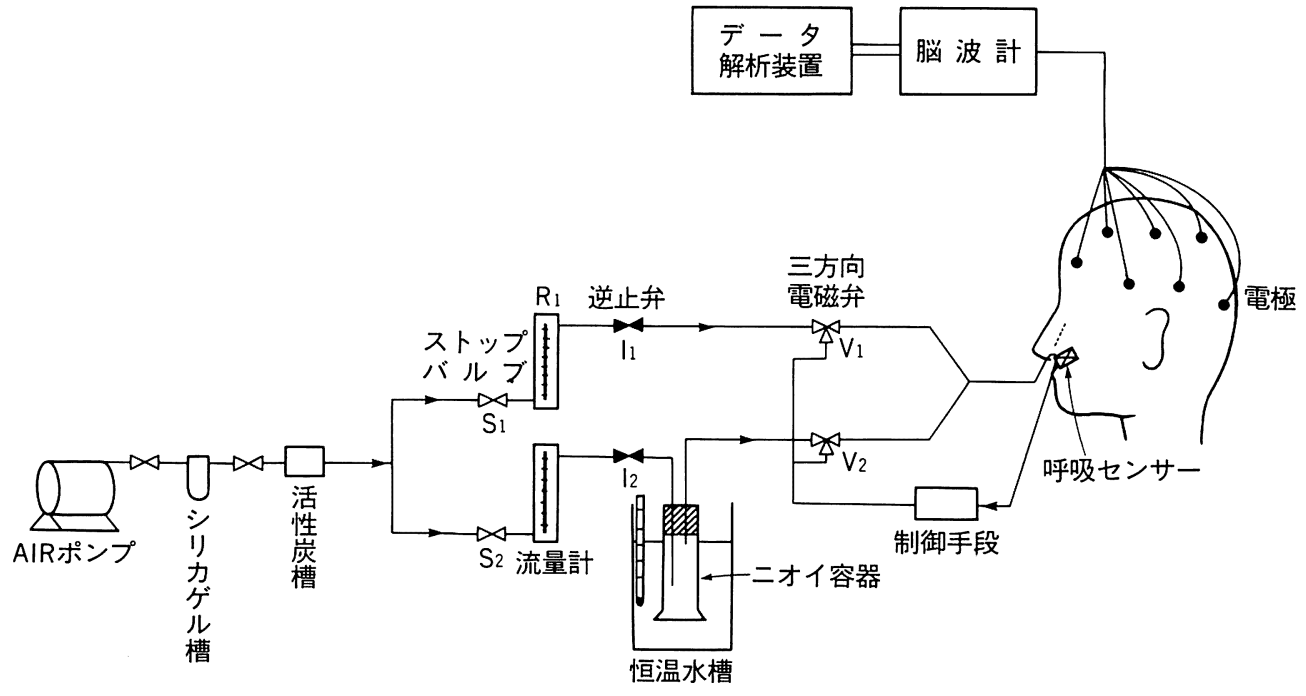

図 3 ニオイパルス刺激装置のブロックダイアグラム 
ガスセンサーを用いて，135 msec と測定され ている.脳波の導出は, 両側乳突部を連結し不 関電極とした。脳波の測定は Ten-twenty electrode system より16ヶ所を選び頭皮上より行っ た.脳波の記録には EEG 1A97 型多用途脳波 計を用いた。前置増幅器の時定数は, 0.3 秒, 高域周波遮断は $60 \mathrm{~Hz}$ とした. ニオイガス刺激 は, 吸気の開始よりある一定時間経過後に電磁 弁を開放させ，4呼吸に 1 回，持続時間 100 msec でニオイガスを投与した. ニオイガスは アミールアセテートとスカトールを用いた。 ま たコントロールとしては無臭空気を用いて誘 発脳波の測定を行った.

ニオイガスによる嗅覚刺激を嗅覚神経系と三 叉神経系に分けることは性状上無理であると考 えたためニオイガスは三叉神経刺激を感じるよ らに嗅裂部に吹きつけて二オイ以外の刺激に差

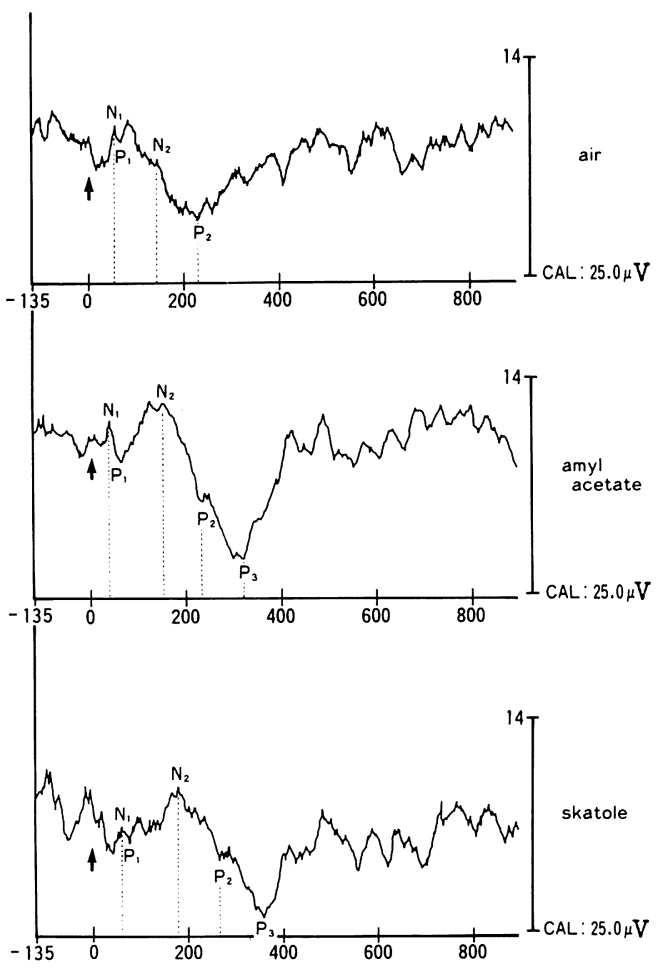

図 4 無臭空気とニオイガス刺激により得られた 誘発波形

*横軸の単位は msec
が認められないように注意して行った。またコ ントロールの無臭空気も同様に嗅裂部に吹き付 け誘発電位を測定した。 その結果, 図 4 のごと く無臭空気で得られた反応波形は N1，P1，N2， P2 で構成され，何れのものにも P3 が認めら れなかった。 またその反応に，ニオイガスによ るものでは二オイを認識できなかった場合を例 外として全て N1，P1，N2，P2，P3 で構成さ れた.このようにして, ニオイ刺激後 150 250 msec の潜時で得られる振幅の小さい N2（陰 性波)，と P2 (陽性波) で構成される早期成分 と, 比較的振幅が大きく潜時 $300 \sim 400 \mathrm{msec} て ゙$ 得られる P3 (陽性波) が後期成分として認め られた。 得られた早期成分 (N2，P2) は三叉神 経系を強く刺激すると振幅の増大が認められ， 逆に，その刺激が減少した場合には振幅が小さ くなる傾向が認められた。このことから，早期 成分は三叉神経系が刺激された結果出現する電 位変化であると考皃た．次に後期成分 (P3) は ニオイを投与し，それを認識したときにのみ出 現するため，二オイの認知に関連して起こる成 分ではないかと考えた。このようにして得られ た誘発波形は三叉神経性成分と嗅覚神経性成分 に分離することが可能であると考えた ${ }^{16)}$.

さらに，嗅神経芽細胞種の診断のもとに手術

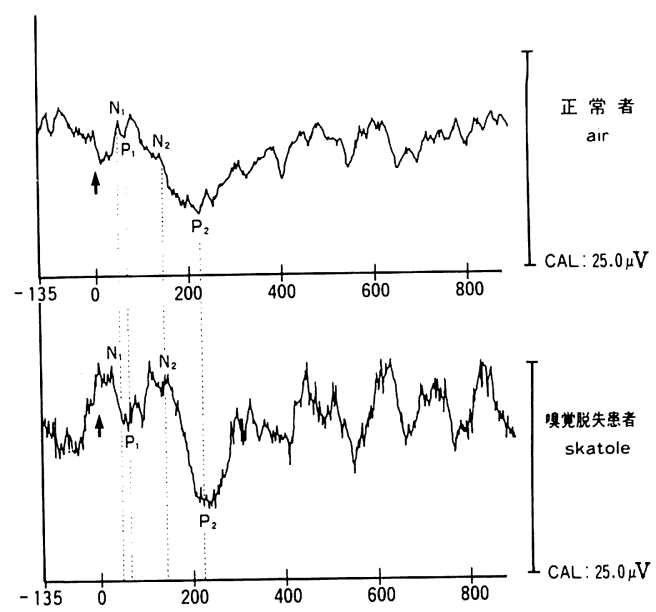

図 5 三叉神経系刺激により得られた誘発波形 
により腫瘍とともに嗅球および，嗅粘膜除去を 行った患者に対してスカトールを投与し，嗅覚 誘発電位の測定を行った。この結果，正常者の 嗅裂部に無臭空気を吹き付け得られた波形と同 様の誘発波が得られた（図 5 ).

このよらな結果，現在までの報告にあるよう に嗅覚刺激に三叉神経刺激を加えることによっ て誘発電位の出現する潜時が早くなるのではな くそれぞれが別の起源をもって出現するのであ ろらと推察した。 また，これらの電位波形に与 えるニオイガスの種類による影響については刺 激を一定にして行うと，波形の潜時や，振幅に 多少変化が認められることから，今後さらに検 討を行らことにより，快や不快といった精神心 理に関係する分野にも発展が期待される.

その他，香りの心理効果を客観的に評価する 手段として CNV (contingent negative variation) を行っている. 具体的には，ニオイガス を与えて (S1)，その 2 秒後に光をみせて (S2), その光をみたらできるだけ早くボタンを押して 光を消すように指示をする，被験者はニオイが
したら次に光がつくのを注意する，そらいった 心の働きに対応して, 前頭葉の能細胞の活動が 高まり，それを反映した特別な脳波 (CNV) を 測定する方法である.

$\mathrm{CNV}$ は前頭部ばかりでなく中心部，頭頂部 にも出現する．その特徵は，鳥居17) によると 図6に示すように，(1)前頭部の CNV では S1 より潜時 500〜1000 msec の間で陰性に向から 電位変動（陰性変動）が目立ち, その後徐々に 消退していく，これを C N V の早期成分という. (2)中心部では, 前頭部と同様に, 早期成分が認 められる. その他, 陰性変動が S2 と運動開始 直前まで続く.これを後期成分といら. (3)頭頂 部では, 前頭部や中心部にみられた早期成分が はっきりせず後期成分のみ顥著にあらわれる。 このよらにして得られた CNV の初期成分は, 注意や期待あるいは予期といった心理的過程を 反映し, 一方, 後期成分は運動準備電位と関連 した電位と考えられている。

従って, 香りの心理効果の客観的評価には, 前頭部の CNV の早期成分が中心に検討されて
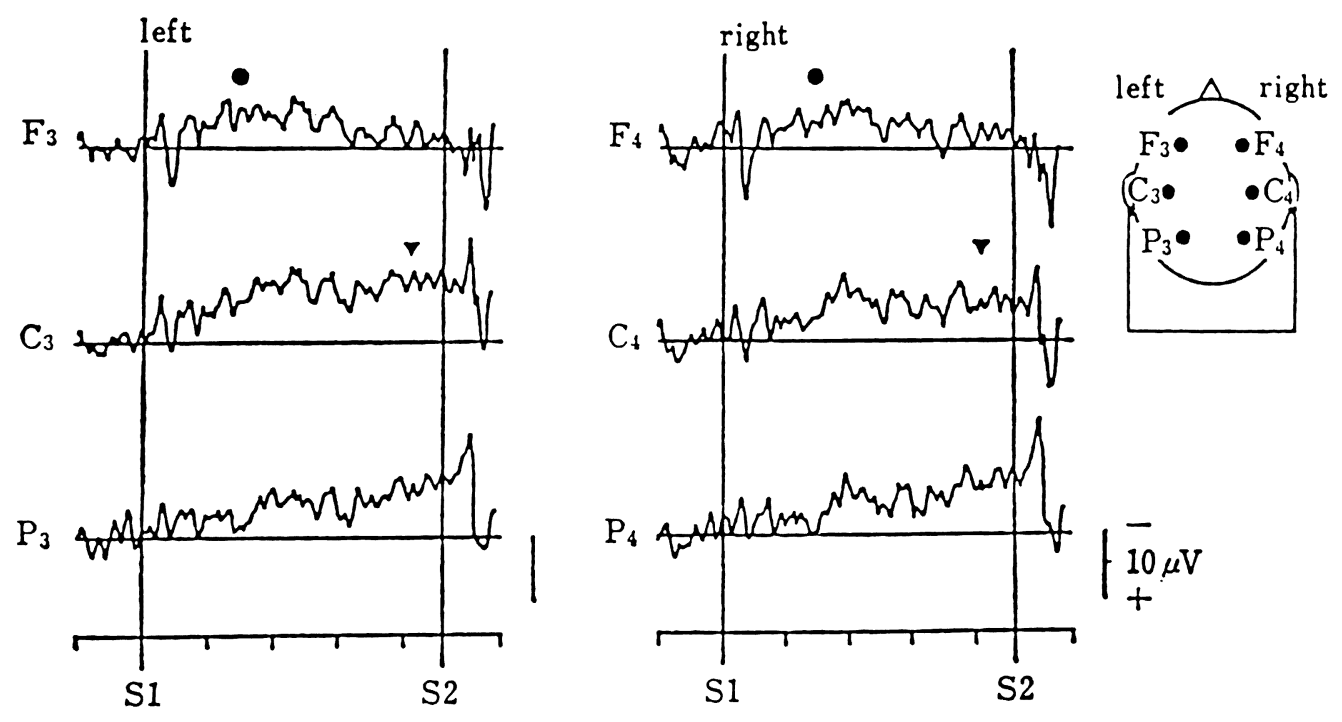

頭皮上の各部位の CNV

$\mathrm{F}$ : 前頭部, $\mathrm{C}$ : 中心部, $\mathrm{P}$ : 頭頂部, ○：早期成分, $\nabla:$ 後期成分

図 6 頭皮上の各部位の CNV（鳥居：1986 17) より引用） 
いる，鳥居17) は，第一刺激にブザー音を用い， $\mathrm{CNV}$ を測定する直前に二オイ瓶のなかの二オ イをかがせて検査を行った．その結果従来から， 興奮作用があるといわれているジャスミンと鎮 静効果があるといわれているラベンダーについ て CNV に及ぼす効果について調べ，ジャスミ ンをかいで CNV を測定した場合には，早期成 分の振幅が大きくなり, 逆に, ラベンダーの場 合にはその振幅が小さくなることを示している. このようにニオイの心理効果を脳波を使って明 らかにする路が開かれつつある。しかし，まだ 一般的には普及して抢らず，今後臨床に対して 応用がなされるものと思われる。

\section{まとめ}

野生動物に执いては外敵より身を守り，種の 存続をはかる等生命の存在自体に重要な役割を 果たしていた二オイが人に执いては快，不快と 言う精神面に重点を扔いて論議されるようにな った。これまでは, 嗅覚障害患者にとって重要 であるはずのニオイに関する問題が，生命には 直接関与しないといらことから軽視される傾向 があった。しかし現代のようなストレスが多い 社会に括いてこそ人間の精神面は尊重されるべ きであり，今後さらに嗅覚あるいはニオイとい らものに対する社会の関心が高まってゆくもの と思われる. 嗅覚障害の程度を把握することは 今現在の段階では不十分であり必ずしも患者の 訴えを適切に評価しているとは言えない，しか し, 社会的な要求が高まっていくなか, 今後嗅 覚といら感覚についても他覚的な評価法の開発 が望まれ，近い将来，快，不快と言う巨視的な 問題についても適切な評価が行われるようにな るものと考える。

稿を終えるにあたり，論文を御校閲下さいました 恩師大阪大学医学部耳鼻咽喉科学教室, 松永 亭教 授に深謝致します。 またご指導, ご協力をいただい た電子総合研究所大阪ライフェレクトロニクス研究 センター外池光雄先生, ならびに飛鳥電機株式会社 吉村真一氏に深く感謝の意を表します。

\section{参考文献}

1) Allison $\mathrm{AC}:$ The structure of the olfactory bulb and its relationship to the olfactory pathways in the rabbit and the rat. J comp Neurol 98 : 309 353, 1953.

2) Tanabe $T$, Iino $M$, Ooshima $Y$, et al : An olfactory area in the prefrontal lobe. Brain Res $80: 127 \sim 130,1974$.

3) Yarita H, Kogure S, Iino $M$, et al : A neural pathway to the oribitofrontal cortex from the olfactory bulb through the thalamus in the monkey. In Olfaction and Taste VI (ed by LeMagnen J and MacLeod P). pp 212, Paris, 1977.

4) Takagi SF : Dual systmes for sensory olfactory processing in higher primates. Trends in Neurosciences, December, 313〜315, 1979.

5）高木貞敬: 嗅覚の中枢機構. 神経研究の進歩 $24: 6 ; 1155 \sim 1175,1980$.

6) 高木貞敬 : 嗅覚の神経生理学的研究の 30 年. 生 体の科学 $35: 67 \sim 79,1984$.

7) Finkenzeller $P$ : Pflugers. Arch Ges Physiol $292: 76 \sim 80,1966$.

8) Allison $T$ and Goff WR : Electroenceph. Clin Neurophysiol $23: 558 \sim 560,1967$.

9) Smith DB, Allison T, Goff WR, et al : Human odorant evoked responses; effects of trigeminal or olfactory deficit. Electoenceph Clin Neurophysiol $30: 313 \sim 317,1971$.

10）大峡星夫：ニオイ刺激による誘発脳波反応の研 究. 耳鼻臨床 $75: 1081 \sim 1104,1982$.

11) Plattig $\mathrm{KH}$ and Kobal G : Spatial and temporal distribution of olfactory evoked potentials and techniques involved in their measurement. Human Evoked Potentials, Plenum Publishing Corporation, New York, 1979.

12) Kobal G and Hummel $C$ : Cerebral chemosensory evoked potentials elicited by chemical stimulation of the human olfactory and respiratory nasal mucosa. Electroenceph clin Neurophysiol $71: 241 \sim 250,1988$.

13）竹本市紅, 野竹敬子, 岡田能理子, 他 : チュー ブを用いた左右別刺激による嗅覚誘発電位の測 定. 第21回味と匂のシンポジウム論文集. 197 
$\sim 199,1987$.

14）野竹敬子, 前谷近秀, 竹本市紅, 他: Blast method による嗅覚誘発電位の測定. 第22回味 と匂のシンポジゥム論文集. 101〜104, 1988.

15）外池光雄, 栗岡 豊: 呼吸同期式嗅覚刺激によ る嗅覚誘発電位の精密検査. 脳波々筋電図 9 : 214 223, 1981.

16）野竹敬子, 前谷近秀, 肥塚 泉, 他: 二オイガ
ス刺激による誘発電位の意義について，第23回 味と旬のシンポジゥム論文集. 43〜 46, 1989.

17）鳥居鎮夫：香りと意識. Fragrance Journal $77: 16 \sim 20,1986$.

(別刷請求先 : 瀬田敬子 空553 大阪市福島区福島1-1-50

大阪大学医学部耳鼾咽喉科学教室) 